Review

\title{
Human Corneal Endothelial Cells Expanded In Vitro Are a Powerful Resource for Tissue Engineering
}

\author{
Yongsong Liu ${ }^{1 *}$, Hong Sun ${ }^{2 *}$, Min $\mathrm{Hu}^{3 *}$, Min Zhu ${ }^{4}$, Sean Tighe ${ }^{5}$, Shuangling Chen ${ }^{5}$, Yuan Zhang 5 , Chenwei \\ $\mathrm{Su}^{5}$, Subo $\mathrm{Cai}^{6}$, Ping Guo ${ }^{7 凶}$ \\ 1. Department of Ophthalmology, Yan' An Hospital of Kunming City, Kunming, 650051, China; \\ 2. Department of Ophthalmology, the First Affiliated Hospital of Nanjing Medical University, Nanjing, 210029, China \\ Department of Ophthalmology, the Second People's Hospital of Yunnan Province, Kunming, 650021, China; \\ Public Health, the University of Arizona, Tucson, Arizona, 85709, USA; \\ 5. Research and Development Department, TissueTech, Inc., 7000 SW 97th Avenue, Suite 212, Miami, FL 33173, USA \\ 6. Department of Ophthalmology, Tongji Hospital, Tongji Medical College, Huazhong University of Science and Technology, Wuhan 430030, Hubei Province, China; \\ 7. Shenzhen Eye Hospital, School of Optometry \& Ophthalmology of Shenzhen University, Shenzhen Key Laboratory of Department of Ophthalmology, Shenzhen, \\ 518000 , China. \\ * These authors contributed equally to this manuscript. \\ $\triangle$ Corresponding author: Ping Guo: Shenzhen Eye Hospital, Zetian Road 18, Room 421, Futian District, Shenzhen, 518000, China. Tel 08613924659029; Fax \\ 08675523959500; Email: 2607212858@qq.com
}

(c) Ivyspring International Publisher. This is an open access article distributed under the terms of the Creative Commons Attribution (CC BY-NC) license (https://creativecommons.org/licenses/by-nc/4.0/). See http://ivyspring.com/terms for full terms and conditions.

Received: 2016.09.18; Accepted: 2016.12.28; Published: 2017.02.07

\begin{abstract}
Human corneal endothelial cells have two major functions: barrier function mediated by proteins such as ZO- 1 and pump function mediated by Na-K-ATPase which help to maintain visual function. However, human corneal endothelial cells are notorious for their limited proliferative capability in vivo and are therefore prone to corneal endothelial dysfunction that eventually may lead to blindness. At present, the only method to cure corneal endothelial dysfunction is by transplantation of a cadaver donor cornea with normal corneal endothelial cells. Due to the global shortage of donor corneas, it is vital to engineer corneal tissue in vitro that could potentially be transplanted clinically. In this review, we summarize the advances in understanding the behavior of human corneal endothelial cells, their current engineering strategy in vitro and their potential applications.
\end{abstract}

Key words: cornea, endothelial, progenitor, regenerative medical application.

\section{Introduction}

The human corneal tissue consists of the epithelium, Bowman's layer, the stroma, Descemet's membrane, and the endothelium. The epithelium is a well-characterized self-renewing layer with stem cells at its peripheral areas. The stroma cells are usually a group of small quiescent cells, which play an important role in maintenance of corneal functions [1]. In contrast, the endothelial cells form a single hexagonal monolayer located at the Descemet's membrane in the posterior cornea [2], and play a significant role in maintaining visual function [3]. As a result of aging, diseases, injury or surgeries, corneal blindness may occur due to dysfunctional human corneal endothelial cells (HCECs), such that there are insufficient numbers and density of HCEC in a disease so called "bullous keratopathy" (reviewed in [4]) or fibroblast metaplasia due to endothelialmesenchymal transition (EMT) [5]. Such EMT also occurs in in vitro culture of HCECs if the cell-cell junctions are disrupted. Interestingly, the conventional approach of isolating HCECs using trypsin-EDTA to break intercellular junctions might cause EMT and change the HCEC phenotype to fibroblastic-like shape [6]. Such change of phenotype has been shown to be due to activation of canonical Wnt signaling in the presence of EGF and/or bFGF, especially when TGF- $\beta 1$ is added which activates canonical TGF- $\beta$ signaling resulting in nuclear translocation of pSmad2/3 and Zeb1/2 [7]. Other groups also showed that TGF- $\beta 1 / 2$ inhibits expansion 
induced by bFGF in trypsin-EDTA treated HCECs [8], rat CECs [9], and bovine CECs [10]. Interestingly, the use of SB431542, a selective inhibitor of the TGF- $\beta R$, may block EMT in HCECs [11]. Since the result of EMT is loss of the normal HCEC phenotype, the inhibition of canonical Wnt-Smad2/3-Zeb1/2 signaling is necessary during the expansion of HCECs. Although HCECs may proliferate in vitro, unfortunately, HCECs do not normally proliferate in vivo [12] due to arrest at the G1 phase in the cell cycle [13]. Hence, corneal blindness may develop as mentioned previously [4,5]. Until now, the only effective medical treatment is by corneal transplantation from healthy donors. In this review, we will review in vitro expansion of corneal endothelial cells, their potential application in the treatment of human blindness and other corneal diseases.

\section{Contact Inhibition of HCECs}

The corneal endothelium form a single hexagonal monolayer located at the Descemet membrane of the posterior cornea and face the TGF- $\beta 2$-containing aqueous humor [14]. Through tight junction ZO-1 and adherent junction Na-K-ATPase, human corneal endothelial cells (HCECs) mediate corneal stromal hydration and transparency via barrier and pump functions, respectively (reviewed in [15]). Unlike murine, rabbit, and bovine cells, HCECs have limited proliferative capability in vivo after aging, injury and surgery [12]. HCECs' limited proliferative capability has been shown to be caused by "contact inhibition" at the G1 phase of the cell cycle (reviewed in [16]). Contact inhibition is also reported in human corneal explants [17], cat explants [18] and rat corneal endothelial cultures [19] when the cells reach confluence.

\section{Expansion of HCECs in Vitro}

\section{Substrates}

The substrates for culturing HCECs have been reported by several groups around the world [17, 20-23]. The attachment and growth of HCECs ex vivo and in vitro can be facilitated by artificial matrices, such as collagen I and fibronectin [24], collagen IV [25, 26], chondroitin sulfate and laminin [27], laminin-5 [28], matrigel [23] and FNC coating mix [29]. Although the substrates such as matrigel, laminin and fibronectin have been widely used for the expansion of HCECs, it has been reported that collagen IV is optimal for the expansion of HCECs for tissue engineering purposes [30].

\section{Media}

Several culture media have been proposed for the expansion of HCECs, for example, Dulbecco's Modified Eagle Medium (DMEM), DMEM/F12, Ham's F12/M199 and Opti-MEM-I [31]. The effect of the four culture medias in the isolation and growth of HCECs were compared by Peh and his associates [32]. They noted that HCECs cultured in these four media quickly attached and expanded when cultured on FNC-coated dishes. Nevertheless, HCECs cultured in DMEM and DMEM/F12 could not be expanded more than the first and second passage. In contrast, HCECs cultured in Opti-MEM-I and Ham's F12/M199 were cultured far beyond the first and second passage (reviewed in [31]). The HCECs cultured in Opti-MEM-I and Ham's F12/M199 within the third passage expressed human corneal endothelial markers such as $\mathrm{Na}+\mathrm{K}+/$ ATPase and ZO-1 (reviewed in [31]), however the cultured HCECs were not hexagonal beyond the third passage. Furthermore, five culture medias were compared for their effect on the survival of corneal endothelium [33]. The five different medias included HCEC growth medium (F99), MEM with 2\% fetal calf serum (FCS), MEM with $5 \%$ FCS, and serum-free medium (SFM). Their conclusion was that the counts of apoptotic cells in the untreated controls was significantly higher when cultured in MEM than those when cultured with F99 and SFM [33]. Zhu et al recommended a medium composed of OptiMEM-I plus $8 \%$ fetal bovine serum (FBS), $20 \mathrm{ng} / \mathrm{mL}$ nerve growth factor (NGF), $5 \mathrm{ng} / \mathrm{mL}$ epidermal growth factor (EGF), $100 \mu \mathrm{g} / \mathrm{mL}$ bovine pituitary extract, $20 \mu \mathrm{g} / \mathrm{mL}$ ascorbic acid, $200 \mathrm{mg} / \mathrm{mL}$ calcium chloride, and $0.08 \%$ chondroitin sulfate for corneal endothelial expansion [29]. Once the cells were confluent, the cultures were switched to a culture medium without fibroblast growth factor (FGF), EGF, NGF, or pituitary extract, for a few days in order to stabilize the morphology of the monolayer which was shown to be similar to that in vivo [29]. They claimed that with this method, primary HCECs might reach confluence within ten days. Recently, a success was reported in the culture and maintenance of HCECs in a serum-free medium called MESCM [34], which is advantageous due to serum-free medium avoiding potential contamination by viruses, bacteria and other infectious agents.

\section{Growth Factors and Cytokines}

Several growth factors have been proposed to promote the growth of HCECs, for example, FGF [17, 20, 22, 27, 35, 36], LIF [34, 37], EGF [6, 20, 22, 25, 26, 36, 38 ], NGF [20] and endothelial cell growth supplement $[22,39]$. It has been suggested that LIF delays contact-inhibition and more effectively promotes 
HCEC growth with bFGF without serum and without change of the phenotype [34, 37].

\section{Endothelial Mesenchymal Transition due to Disruption of Cell-Cell Junctions Is the Obstacle for in Vitro Growth of HCECs}

Contact-inhibition is present in non-transformed normal cells when neighboring cells are in contact with one another. This fact causes low regenerative capability of in vivo human corneal endothelial cells. The conventional approach to grow HCECs in vitro is to break the cell-cell junctions by trypsin-EDTA and culture them in a medium containing growth factors such as FGF [27]. However, such a culture method may cause "endothelial-mesenchymal transformation" (EMT), which is a pathologic process that may eventually result in corneal blindness (reviewed in [5]). It is believed that the use of trypsin-EDTA to break the cell-cell junctions and then to culture HCECs in a bFGF-containing medium causes EMT via activation of the canonical Wnt signaling, especially when TGF- $\beta 1$ signaling is also activated [6].

In contact-inhibited cultures of HCEC monolayers $[25,26]$, a short exposure of the HCEC monolayers to $5 \mathrm{mM}$ EDTA for $1 \mathrm{~h}$ results in significant disruption of intercellular junction [6]. Without FGF, cells recover their pre-treated monolayer morphology in 2 days. However, when 20 $\mathrm{ng} / \mathrm{ml} \mathrm{FGF}$ is present for 2 days, $10 \mathrm{ng} / \mathrm{ml}$ TGF $\beta 1$ is present for 3 days, or $20 \mathrm{ng} / \mathrm{ml}$ FGF is present for 2 days followed by $10 \mathrm{ng} / \mathrm{ml}$ TGF $\beta 1$ for 3 days, HCECs turn into fibroblastic-like cells because of EMT. This phenomenon is closely associated with activation of canonical Wnt signaling and canonical TGF- $\beta$-Smad $2 / 3$ signaling [6]. A similar result is also noted in contact-inhibited ARPE-19 epithelial cells [7] [40]. Remarkably, a 5-minute treatment of trypsin/EDTA caused fibroblastic shape change of appearance in contact-inhibited HCEC monolayers within $24 \mathrm{~h}$, which failed to fully recover the hexagonal shape 28 days later in EGF-containing SHEM [34]. This morphological alteration was accompanied by activation of canonical Wnt signaling as evidenced by nuclear localization of $\beta$-catenin and LEF1, 4- and 6-fold increase of transcript expression of $\beta$-catenin and LEF1, 13- and 15-fold elevation of nuclear $\beta$-catenin and LEF1, and 17-fold increase of TCF/LEF promoter activity [34].

\section{Novel Expansion of HCECs with Normal Phenotype by Preserving Cell-Cell Junctions}

An in vitro model system of HCEC monolayers has been established that exhibit a mitotic block regulated via contact inhibition, which preserves cell-cell junction and cell-matrix interaction during isolation and subsequent expansion [25] [26]. Remarkably, the contact inhibition of HCEC monolayers can safely be perturbed by transient knockdown with p120 catenin and Kaiso siRNAs, which activates non-canonical BMP-NFkB signaling in SHEM without disrupting the intercellular junction and without causing EMT after collagenase digestion of HCECs [6] [34]. This p120-Kaiso signaling is linked to activation of RhoA-ROCK signaling, which destabilizes microtubules, and inhibits Hippo signaling, but not Wnt signaling. As a result, human corneal endothelial cells maintain a hexagonal shape with junctional expression of N-cadherin, ZO-1, and Na-K-ATPase during their growth [6]. Such engineering technology has successfully produced HCEC monolayers with a hexagonal shape and in vivo cell density [6] [34].

Without p120-Kaiso knockdown, MESCM promoted growth of HCEC monolayers in diameter from $1.4 \mathrm{~mm}$ in SHEM to $4.4 \mathrm{~mm}$ after 6 weeks of culture. With p120-Kaiso knockdown, MESCM promoted growth of HCEC monolayers from $5.0 \mathrm{~mm}$ in SHEM to $11.0 \mathrm{~mm}$ in diameter, i.e., a good size for clinical transplantation. BrdU labeled nuclei were only found in MESCM $[6,34]$. The proliferative effect regulated by non-canonical BMP signaling in SHEM was not linked to higher mRNA expression of embryonic stem cell and neural crest cell markers. In contrast, such dramatic proliferative effect was associated with higher transcript expression of embryonic stem cell markers such as Nanog, Nestin, Oct4, Sox2, SSEA4 and neural crest markers, for example AP2 $\beta$, FOXD3, and SOX9, which was completely blocked by BMP inhibitor noggin, indicating that the reprogramming is controlled by the canonical BMP signaling [34]. Correspondingly, immunostaining staining of FOXD3, Nanog, Nestin, Oct 4, SOX2, SOX9 and SSEA4 was found in p120 or p120-Kaiso siRNA treated HCECs [34]. In addition, Nanog, Oct 4 and SOX-2 were translocated to the nucleus with a significant increase in the expression of miRNA $302 b^{*}$ and miRNA $302 c^{*}$ only in p120 or p120-Kaiso siRNA treated HCECs [34], indicating that the cells were in active reprogramming. Furthermore, such over-expression and nuclear translocation of ESC markers and neural crest markers was attenuated by noggin, an extracellular BMP inhibitor [34]. These findings support the notion that the switch from non-canonical to canonical BMP signaling results in the reprogramming of HCECs to embryonic- or neural crest-like progenitors. Because such a reprogramming process was completely blocked by Noggin, which also blocked BrdU labeling, the 
effective growth of HCEC monolayers is successful due to the activation of canonical BMP signaling in MESCM that reprograms HCECs into their progenitor status [6] [34]. Remarkably, withdrawal of p120 siRNA in SHEM maintains in vivo morphology, density and phenotype [6,34], which is also true when the cells are cultured in MESCM [34]. Compared to the in vivo HCECs, the resultant cell shape retained hexagonal shape during the entire experimental period (i.e. 5 weekly treatments of p120-Kaiso siRNAs followed by withdrawal for one week) for both scrambled(sc)RNA and p120-Kaiso siRNA [34]. The final HCEC monolayer maintained expression of acetylate- $\alpha$-catenin (a marker of cilium), cytoplasmic expression of $\gamma$-tubulin and p75NTR, junctional expression of $\alpha$-catenin, $\beta$-catenin, F-actin Na-K-ATPase, N-cadherin, p120 and ZO-1 (the markers of HCECs), and without enhanced transcript expression of LEF1 and S100A4 (the markers of EMT) [34]. The expression pattern is similar to that in vivo, reported previously [26].

\section{Human Corneal Endothelial Progenitors Are Powerful Resources of HCEC Regeneration}

Hatou et al (2013) reported that functional corneal endothelium can be obtained from corneal stromal stem cells of neural crest origin, called cornea derived precursors (COPs) [41]. Hatou et al isolated human COPs by $400 \mathrm{U} / \mathrm{ml}$ type I collagenase digestion, expanded them on plastic at a density of $1 \times$ $10^{5} \mathrm{~cm}^{2}$ in a medium containing 1:1 DMEM/F-12 supplemented with $20 \mathrm{ng} / \mathrm{ml}$ EGF, $20 \mathrm{ng} / \mathrm{ml} \mathrm{bFGF}$, B27 and N2 for 1 week [41]. The researchers then reprogrammed these single progenitor cells into HCECs by seeding at the density of $2 \times 10^{5} \mathrm{~cm}^{2}$ on $0.1 \%$ gelatin or $1.0 \mathrm{mg} / \mathrm{ml}$ laminin- or type I collagen -coated dishes in MEM supplemented with 1\% FBS, 1 $\mathrm{mM}$ all-trans retinoic acid, $1 \mathrm{mM}$ GSK $3 \beta$ inhibitor (6-bromoindirubin-3'-oxime), $5 \mathrm{ng} / \mathrm{ml}$ TGF $\beta 2,10 \mathrm{mM}$ ROCK inhibitor Y-27632, and $1 \mathrm{mM}$ insulin for 1 week. The authors used endothelial markers such as Atp1a1, Slc4a4, Car2, Col4a2, Col8a2, and Cdh2 (and Pitx2, a homeobox gene involved in the development of the anterior segment of the eye) to demonstrate the endothelial characteristics, and showed the Na-K-ATPase activity expressed by endothelial cells. However, p120, ZO-1, F-actin, N-cadherin, $\beta$-catenin and Na-K-ATPase were also used to characterize the HCEC phenotype [6]. In contrast, Hara et al (2013) reported that HCECs can be generated from human corneal endothelial progenitors (HCEPs) with neural crest phenotype [42]. This group of scientists used enzyme cell detachment medium (accutase, Life
Technology) to detach the cells from Descemet membranes, expanded the cells in a medium containing 1:1 DMEM/F12, 20\% knockout serum, 4 $\mathrm{ng} / \mathrm{ml}$ bFGF on laminin 511, differentiated the cells in a low glucose DMEM with 10\% FBS on FNC coated dishes in 3-4 weeks, and used neural crust markers such as P75NTR, AP2 $\beta$, SOX-9, Snail, Slug and PITX2 to demonstrate the neural crust phenotype of HCEPs. The authors also used COL8A1 and COL8A2 as HCEC markers, FOXC-2 as a mesenchymal marker to demonstrate their mesenchymal characteristics and colony formation assay to demonstrate their cells have stem-cell like characteristics, and determined Na-K-ATPase activity to demonstrate that the cells have pump function similar to endothelial cells. It is unclear whether neural crest like cells generated from HCF can differentiate into HCECs in MEM supplemented with $1 \%$ FBS, $1 \mathrm{mM}$ all-trans retinoic acid, $1 \mathrm{mM}$ GSK $3 \beta$ inhibitor (6-bromoindirubin-3'oxime), $5 \mathrm{ng} / \mathrm{ml}$ TGF $\beta 2,10 \mathrm{mM}$ ROCK inhibitor Y-27632, and $1 \mathrm{mM}$ insulin, or in a low glucose DMEM with $10 \%$ FBS on FNC coated dishes. It is also unclear whether the neural crest cells generated from HCF can differentiate into keratocytes, if so, whether culture of the neural crest like cells generated from HCF in Hatou expansion medium could expand the neural crest like cells, and if so, whether the neural crest like cells can differentiate into HCECs or other type of cells.

The culture methods from Hatou (2013) [41] and Hara (2013) [42] are summarized in Table 1.

Although a number of groups have reported the presence of human corneal endothelial progenitor cells [43-47], the detailed features of the progenitors, including whether the progenitors can be reprogrammed into neural crest progenitors and whether such reprogrammed progenitors have multi-plasticity and more proliferative potential have not been revealed until recently. It has been reported that transient knockdown with p120 catenin (p120) and Kaiso siRNAs activates p120-Kaiso-RhoA-ROCK-canonical BMP signaling when cultured in LIF and bFGF-containing MESCM [34], which results in effective growth of HCEC monolayers because of reprogramming adult HCECs into their progenitor status [34]. It has also been reported by the same group that without p120-Kaiso knockdown, transit activation of LIF-JAK1-STAT3 signaling may promote growth of human corneal endothelial progenitor cells by delaying contact-inhibition but not reprogramming [37], suggesting that LIF-mediated signaling acts synergistically with BMP signaling to promote the reprogramming and expansion of HCEC monolayers. 
Table 1. Methods for isolation and expansion of human corneal progenitors and their differentiation to corneal endothelial cells.

\begin{tabular}{|c|c|c|c|c|c|c|c|c|c|c|}
\hline \multirow[t]{2}{*}{ Purpose } & \multirow{2}{*}{$\begin{array}{l}\text { Cell } \\
\text { Name }\end{array}$} & \multirow[t]{2}{*}{ Isolation } & \multirow{2}{*}{$\begin{array}{l}\text { Culture } \\
\text { Cell } \\
\text { Density }\end{array}$} & \multicolumn{4}{|c|}{ Growth Medium } & \multirow[t]{2}{*}{ Substrate } & \multirow[t]{2}{*}{ Time } & \multirow[t]{2}{*}{ References } \\
\hline & & & & $\begin{array}{l}\text { Basal } \\
\text { Medium }\end{array}$ & $\begin{array}{l}\text { Serum } \\
(\%)\end{array}$ & $\begin{array}{l}\text { Growth } \\
\text { Factors }\end{array}$ & Supplements & & & \\
\hline Expansion & HCEPs & $\begin{array}{l}\text { Cell detachment } \\
\text { Medium } \\
\text { (Accutase) }\end{array}$ & $\begin{array}{l}100-300 \\
\text { cells } / \mathrm{cm}^{2}\end{array}$ & $\begin{array}{l}\text { 1:1 } \\
\text { DMEM/F12 }\end{array}$ & $\begin{array}{l}20 \% \mathrm{KO} \\
\text { Serum }\end{array}$ & $\begin{array}{l}4 \mathrm{ng} / \mathrm{ml} \\
\mathrm{bFGF}\end{array}$ & & $\begin{array}{l}20 \mu \mathrm{g} / \mathrm{ml} \\
\text { Laminin } 511\end{array}$ & $\begin{array}{l}\text { To } \\
\text { sub-confluence }\end{array}$ & Hara, 2013 \\
\hline Differentiation & HCECS & Accutase & $\begin{array}{l}\text { Passaged } \\
1: 2\end{array}$ & $\begin{array}{l}\text { Low Glucose } \\
\text { DMEM }\end{array}$ & $10 \%$ & & & FNC Mix & 3-4 Weeks & Hara, 2013 \\
\hline Expansion & COPs & $\begin{array}{l}400 \mathrm{U} / \mathrm{ml} \text { type I } \\
\text { collagenase }\end{array}$ & $\begin{array}{l}1 \times 10^{5} \\
\text { Cells } / \mathrm{cm}^{2}\end{array}$ & $\begin{array}{l}\text { 1:1 } \\
\text { DMEM/F12 }\end{array}$ & & $\begin{array}{l}20 \mathrm{ng} / \mathrm{ml} \\
\mathrm{EGF}, 20 \\
\mathrm{ng} / \mathrm{ml} \\
\mathrm{bFGF}\end{array}$ & B27 and N2 & None & $\begin{array}{l}\text { Not found in the } \\
\text { Paper }\end{array}$ & $\begin{array}{l}\text { Hatou, } \\
2013\end{array}$ \\
\hline Differentiation & HCECS & $?$ & $\begin{array}{l}2 \times 10^{5} \\
\text { Cells } / \mathrm{cm}^{2}\end{array}$ & MEM & $1 \%$ & $\begin{array}{l}5 \mathrm{ng} / \mathrm{ml} \\
\text { TGF } \beta 2\end{array}$ & $\begin{array}{l}1 \mathrm{mM} \text { all-trans retinoic acid, } 1 \\
\text { mM GSK } 3 \beta \text { inhibitor } \\
\text { (6-bromoindirubin-3'-oxime), } \\
10 \mathrm{mM} \text { ROCK inhibitor } \\
\text { Y-27632, } 1 \mathrm{mM} \text { insulin. }\end{array}$ & $\begin{array}{l}0.1 \% \text { gelatin; } 1 \\
\mu \mathrm{g} / \mathrm{ml} \text { laminin; } \\
1 \mu \mathrm{g} / \mathrm{ml} \text { type I } \\
\text { collagen }\end{array}$ & 1 week & $\begin{array}{l}\text { Hatou, } \\
2013\end{array}$ \\
\hline
\end{tabular}

Interestingly, the delay of contact-inhibition is via inhibition of nuclear translocation of p16INK4a, important cyclin-dependent kinase inhibitors (CKIs) in the cell cycle regulation [37].

In mammalian cells, the G1/S transition is blocked through contact-inhibition. The cell cycle progression is negatively controlled by contact inhibition but facilitated by E2F, of which the activity is negatively regulated by non-phosphorylated retinoblastoma tumor suppressor $(\mathrm{Rb})$ [48]. Release of inhibition mediated by phosphorylation of $\mathrm{Rb}$ is controlled positively by cyclin D1/cyclin-dependent kinase-4 (CDK4) and cyclin E/CDK2 complex, but negatively by cyclin-dependent kinase inhibitors (CKIs) such as p16INK4a, p15INK4b, p18INK4c, p19INK4d, p21CIP1, p27KIP1, and p57KIP2 [49]. Without p120-Kaiso knockdown, it has been reported that LIF-JAK1-STAT3 signaling delays contact inhibition but not reprogramming of HCEC monolayers [37], suggesting that canonical BMP signaling is indeed critical for reprogramming induced by p120 and Kaiso siRNAs in MESCM [34]. In this case, the miR-302 cluster acts on multiple targets to promote human somatic cell reprogramming [50], nucleus-translocated Oct4, Sox2, and Nanog may activate expression of this miR-302 cluster $[51,52]$ and miR-302 may indirectly mediate expression of Oct4, Sox2, and Nanog [53, 54], suggesting that miR 302 plays a significant role in such reprogramming. Although more work is needed to illustrate the detailed mechanism of reprogramming of HCECs and other cells into their progenitor status, more evidence has indicated that p16INK4a plays an important role in the reprogramming process, which can be negatively mediated by Bmi1 [55-57]. Still there is a controversial report that states Rho kinase inhibitor Y-27632 enables cell-based therapy for corneal endothelial dysfunction [58].

\section{Potential Clinical Application of Human Corneal Endothelial Grafts after Pre-Clinical Animal Studies}

In past decades, several laboratories have reported a number of carriers for the construction of HCEC sheets. Initially, full-thickness corneal transplantations of reconstructed grafts with cultured human CECs [59-61] and animal CECs were performed in rabbit $[62,63]$, bovine [64], cat [65] and murine [66]. As early as 1979, the CEC sheets constructed with cultured CECs were tested in bovine and rabbit models (i.e. bovine corneal endothelial cells were transplanted onto bovine and rabbit corneas denuded of their endothelium) [62, 65]. Subsequently, cultured HCECs were tested on human corneas denuded of the endothelium $[17,67,68]$.

Due to rapid hydration of the grafted PIPAAm, adherent culture of the cells might be separated spontaneously from these surfaces by decreasing culture temperature without the need for proteolytic enzymes [69]. The cells in the HCEC sheets were mostly hexagonal with a lot of microvilli and cilia, resembling the native corneal endothelium under electron microscopy. Lai and his associates also expanded HCECs on a thermoresponsive type of PNIPAAm as a carrier of cultivated HCEC grafts [70]. Choi and his associates used decellularized thin-layer human corneal stroma as a carrier [71]. Liang and his associates also developed a chitosan-based membrane made of hydroxyethyl chitosan, gelatin, and chondroitin sulfate as a new carrier of cultured HCEC sheets [72]. In addition, Nishida and his associates created gelatin hydrogels as a carrier for HCECs [73]. Gelatin hydrogel discs was also tested as a carrier of cultured HCEC sheets [70]. Decellularized thin-layer human corneal stroma was also tested as a carrier [71]. A chitosan-based membrane consisting of gelatin, 
hydroxyethyl chitosan and chondroitin sulfate was used as a carrier of HCEC grafts in vitro [72]. Similarly, gelatin hydrogels were tested as carrier sheets of HCEC grafts [73] and collagen I carrier used for in vitro monkey CEC grafts [74, 75]. A comprehensive review has been published recently to guide tissue engineering of human corneal endothelial grafts (reviewed in [30]).

Despite this progress, there still remain some major challenges in this field. For instance, there is no clear established animal model to test these engineered HCEC grafts that will correlate to clinical success in humans. It has been reported that Dr. Tseng's group have been testing their HCEC grafts generated from HCEC progenitors in a mini-pig model recently. Mini-pigs have reported similar anatomical ocular characteristics to humans and swine CECs do not proliferate in vivo which may make it a viable option. Such test is promising because if successful, the grafts can be used for curing the blindness due to deficiency of human corneal endothelial cells, a common disease in this world. In fact, a clinical trial for endothelial cells is currently in progress, suggesting the cultivated ocular cells are a promising alternative in the future (reviewed in [76]). However, such transplantation of HCECs may be dependent on their surgical manipulation and further testing will be needed on their stability, sterility, purity and viability to fulfill the rigorous demands of notified bodies for approval.

\section{Conclusion}

New techniques of endothelial keratoplasty surgery with healthy HCEC have quickly replaced conventional penetrating keratoplasty surgery as a preferred procedure for clinical treatment of endothelial diseases. This review has highlighted the latest discoveries and innovations in engineering HCEC grafts to overcome the worldwide shortage of donor corneas. The novel techniques presented in this article are good examples for clinical treatments of CEC dysfunction. Since CECs from the peripheral cornea contain more CEC precursors than CECs from the central cornea in a rabbit model [77] and a human model [46], expansion of peripheral cells by MESCM and p120-Kaiso knockdown may eventually be successful in transplantation of HCEC grafts [34]. Such reprogramming of HCEC progenitors should facilitate engineering of HCEC grafts for repair and regeneration of human corneal endothelium. Innovative breakthroughs of engineered HCEC grafts in vitro is now promising to bring cultivated HCECs from bench to bedside.

\section{Abbreviations}

bFGF: Basic fibroblast growth factor

BMP: Bone morphogenic protein

BrdU: Bromodeoxyuridine

DLEK: Deep lamellar endothelial keratoplasty

DMEK: Descemet membrane endothelial keratoplasty

DSAEK: Descemet stripping automated endothelial

keratoplasty

EK: Endothelial keratoplasty

EDTA: Ethylenediaminetetraacetic acid

EMT: Endothelial-mesenchymal transition

EGF: Epidermal growth factor

HCECs: human corneal endothelial cells

LEF1: lymphoid enhancer-binding factor 1

LIF: Leukemia inhibitory factor

NGF: Nerve growth factor

MESCM: modified embryonic stem cell medium

P120: p120 catenin

RPE: retinal pigment epithelial cells

siRNA: Small interfering ribonucleic acid

SHEM: supplemental hormonal epithelial medium

TGF: Transforming growth factor

\section{Acknowledgement}

This work was supported by Grant JCY20130401152829824 from Shenzhen Municipal Science and Technology Innovation Committee and Grant 2015A030313774 from Natural Science Foundation of Guangdong Province.

\section{Competing Interests}

The authors have declared that no competing interest exists.

\section{References}

1. Ebrahimi M, Taghi-Abadi E, Baharvand H. Limbal stem cells in review. J Ophthalmic Vis Res. 2009; 4: 40-58.

2. Bahn CF, Falls HF, Varley GA, Meyer RF, Edelhauser HF, Bourne WM. Classification of corneal endothelial disorders based on neural crest origin. Ophthalmology. 1984; 91: 558-63.

3. Bonanno JA. Identity and regulation of ion transport mechanisms in the corneal endothelium. Prog Retin Eye Res. 2003; 22: 69-94.

4. Bourne WM, McLaren JW. Clinical responses of the corneal endothelium. Exp Eye Res. 2004; 78: 561-72.

5. Lee JG, Kay EP. FGF-2-mediated signal transduction during endothelial mesenchymal transformation in corneal endothelial cells. Exp Eye Res. 2006; 83: 1309-16.

6. Zhu YT, Chen HC, Chen SY, Tseng SC. Nuclear p120 catenin unlocks mitotic block of contact-inhibited human corneal endothelial monolayers without disrupting adherent junctions. J Cell Sci. 2012; 125: 3636-48.

7. Chen HC, Zhu YT, Chen SY, Tseng SC. Wnt signaling induces epithelial-mesenchymal transition with proliferation in ARPE-19 cells upon loss of contact inhibition. Lab Invest. 2012; 92: 676-87.

8. Rieck P, Oliver L, Engelmann K, Fuhrmann G, Hartmann C, Courtois Y. The role of exogenous/endogenous basic fibroblast growth factor (FGF2) and transforming growth factor beta (TGF beta-1) on human corneal endothelial cells proliferation in vitro. Exp Cell Res. 1995; 220: 36-46.

9. Joyce NC. Proliferative capacity of the corneal endothelium. Prog Retin Eye Res. 2003; 22: 359-89.

10. Lu J, Lu Z, Reinach P, Zhang J, Dai W, Lu L, et al. TGF-beta2 inhibits AKT activation and FGF-2-induced corneal endothelial cell proliferation. Exp Cell Res. 2006; 312: 3631-40.

11. Okumura N, Kay EP, Nakahara M, Hamuro J, Kinoshita S, Koizumi N. Inhibition of TGF-beta signaling enables human corneal endothelial cell expansion in vitro for use in regenerative medicine. PLoS One. 2013; 8: e58000. 
12. Laing RA, Neubauer L, Oak SS, Kayne HL, Leibowitz HM. Evidence for mitosis in the adult corneal endothelium. Ophthalmology. 1984; 91: 1129-34.

13. Joyce NC, Meklir B, Joyce SJ, Zieske JD. Cell cycle protein expression and proliferative status in human corneal cells. Invest Ophthalmol Vis Sci. 1996; 37: 645-55.

14. Chen KH, Harris DL, Joyce NC. TGF-beta2 in aqueous humor suppresses S-phase entry in cultured corneal endothelial cells. Invest Ophthalmol Vis Sci. 1999; 40: 2513-9.

15. Terry MA. Endothelial keratoplasty: history, current state, and future directions. Cornea. 2006; 25: 873-8.

16. Joyce NC. Cell cycle status in human corneal endothelium. Exp Eye Res. 2005; 81: 629-38.

17. Engelmann K, Friedl P. Optimization of culture conditions for human corneal endothelial cells. In Vitro Cell Dev Biol. 1989; 25: 1065-72.

18. Petroll WM, Jester JV, Bean JJ, Cavanagh HD. Myofibroblast transformation of cat corneal endothelium by transforming growth factor-beta1, -beta2, and -beta3. Invest Ophthalmol Vis Sci. 1998; 39: 2018-32.

19. Joyce NC, Harris DL, Mello DM. Mechanisms of mitotic inhibition in corneal endothelium: contact inhibition and TGF-beta2. Invest Ophthalmol Vis Sci. 2002; 43: 2152-9.

20. Chen KH, Azar D, Joyce NC. Transplantation of adult human corneal endothelium ex vivo: a morphologic study. Cornea. 2001; 20: 731-7.

21. Ishino Y, Sano Y, Nakamura T, Connon CJ, Rigby H, Fullwood NJ, et al. Amniotic membrane as a carrier for cultivated human corneal endothelial cell transplantation. Invest Ophthalmol Vis Sci. 2004; 45: 800-6.

22. Yue BY, Sugar J, Gilboy JE, Elvart JL. Growth of human corneal endothelial cells in culture. Invest Ophthalmol Vis Sci. 1989; 30: 248-53.

23. Miyata K, Drake J, Osakabe Y, Hosokawa Y, Hwang D, Soya K, et al. Effect of donor age on morphologic variation of cultured human corneal endothelial cells. Cornea. 2001; 20: 59-63.

24. Joyce NC, Zhu CC. Human corneal endothelial cell proliferation: potential for use in regenerative medicine. Cornea. 2004; 23: S8-S19.

25. Li W, Sabater AL, Chen YT, Hayashida Y, Chen SY, He H, et al. A novel method of isolation, preservation, and expansion of human corneal endothelial cells. Invest Ophthalmol Vis Sci. 2007; 48: 614-20.

26. Zhu YT, Hayashida Y, Kheirkhah A, He H, Chen SY, Tseng SC. Characterization and comparison of intercellular adherent junctions expressed by human corneal endothelial cells in vivo and in vitro. Invest Ophthalmol Vis Sci. 2008; 49: 3879-86.

27. Engelmann $\mathrm{K}$, Bohnke $\mathrm{M}$, Friedl P. Isolation and long-term cultivation of human corneal endothelial cells. Invest Ophthalmol Vis Sci. 1988; 29: 1656-62.

28. Yamaguchi M, Ebihara N, Shima N, Kimoto M, Funaki T, Yokoo S, et al. Adhesion, migration, and proliferation of cultured human corneal endothelial cells by laminin-5. Invest Ophthalmol Vis Sci. 2011; 52: 679-84.

29. Zhu C, Joyce NC. Proliferative response of corneal endothelial cells from young and older donors. Invest Ophthalmol Vis Sci. 2004; 45: 1743-51.

30. Zhu YT, Tighe S, Chen SL, John T, Kao WY, Tseng SC. Engineering of Human Corneal Endothelial Grafts. Curr Ophthalmol Rep. 2015; 3: 207-17.

31. Mimura T, Yokoo S, Yamagami S. Tissue engineering of corneal endothelium. J Funct Biomater. 2012; 3: 726-44.

32. Peh GS, Toh KP, Wu FY, Tan DT, Mehta JS. Cultivation of human corneal endothelial cells isolated from paired donor corneas. PLoS One. 2011; 6: e28310.

33. Jackel T, Knels L, Valtink M, Funk RH, Engelmann K. Serum-free corneal organ culture medium (SFM) but not conventional minimal essential organ culture medium (MEM) protects human corneal endothelial cells from apoptotic and necrotic cell death. Br J Ophthalmol. 2011; 95: 123-30.

34. Zhu YT, Li F, Han B, Tighe S, Zhang S, Chen SY, et al. Activation of RhoA-ROCK-BMP signaling reprograms adult human corneal endothelial cells. J Cell Biol. 2014; 206: 799-811.

35. Engelmann K, Friedl P. Growth of human corneal endothelial cells in a serum-reduced medium. Cornea. 1995; 14: 62-70.

36. Samples JR, Binder PS, Nayak SK. Propagation of human corneal endothelium in vitro effect of growth factors. Exp Eye Res. 1991; 52: 121-8.

37. Liu X, Tseng SC, Zhang MC, Chen SY, Tighe S, Lu WI, et al. LIF-JAK1-STAT3 signaling delays contact inhibition of human corneal endothelial cells. Cell Cycle. 2015; 14: 1197-206

38. Schultz G, Cipolla L, Whitehouse A, Eiferman R, Woost P, Jumblatt M. Growth factors and corneal endothelial cells: III. Stimulation of adult human corneal endothelial cell mitosis in vitro by defined mitogenic agents. Cornea. 1992; 11: 20-7.

39. Blake DA, Yu H, Young DL, Caldwell DR. Matrix stimulates the proliferation of human corneal endothelial cells in culture. Invest Ophthalmol Vis Sci. 1997; 38: 1119-29.

40. Chen HC, Zhu YT, Chen SY, Tseng SC. Selective activation of p120ctn-Kaiso signaling to unlock contact inhibition of ARPE-19 cells without epithelial-mesenchymal transition. PLoS One. 2012; 7: e36864.

41. Hatou S, Yoshida S, Higa K, Miyashita H, Inagaki E, Okano H, et al. Functional corneal endothelium derived from corneal stroma stem cells of neural crest origin by retinoic acid and Wnt/beta-catenin signaling. Stem Cells Dev. 2013; 22: 828-39.

42. Hara S, Hayashi R, Soma T, Kageyama T, Duncan T, Tsujikawa M, et al Identification and potential application of human corneal endothelial progenitor cells. Stem Cells Dev. 2014; 23: 2190-201.
43. He Z, Campolmi N, Gain P, Ha Thi BM, Dumollard JM, Duband S, et al. Revisited microanatomy of the corneal endothelial periphery: new evidence for continuous centripetal migration of endothelial cells in humans. Stem Cells. 2012; 30: 2523-34.

44. McGowan SL, Edelhauser HF, Pfister RR, Whikehart DR. Stem cell markers in the human posterior limbus and corneal endothelium of unwounded and wounded corneas. Mol Vis. 2007; 13: 1984-2000.

45. Whikehart DR, Parikh CH, Vaughn AV, Mishler K, Edelhauser HF. Evidence suggesting the existence of stem cells for the human corneal endothelium. Mol Vis. 2005; 11: 816-24.

46. Yamagami S, Yokoo S, Mimura T, Takato T, Araie M, Amano S. Distribution of precursors in human corneal stromal cells and endothelial cells. Ophthalmology. 2007; 114: 433-9.

47. Yokoo S, Yamagami S, Yanagi Y, Uchida S, Mimura T, Usui T, et al. Human corneal endothelial cell precursors isolated by sphere-forming assay. Invest Ophthalmol Vis Sci. 2005; 46: 1626-31.

48. DeGregori J, Leone G, Miron A, Jakoi L, Nevins JR. Distinct roles for E2F proteins in cell growth control and apoptosis. Proc Natl Acad Sci U S A. 1997; 94: 7245-50.

49. Sherr CJ, Roberts JM. Inhibitors of mammalian G1 cyclin-dependent kinases. Genes Dev. 1995; 9: 1149-63.

50. Subramanyam D, Lamouille S, Judson RL, Liu JY, Bucay N, Derynck R, et al. Multiple targets of miR-302 and miR-372 promote reprogramming of human fibroblasts to induced pluripotent stem cells. Nat Biotechnol. 2011; 29: 443-8.

51. Card DA, Hebbar PB, Li L, Trotter KW, Komatsu Y, Mishina Y, et al. Oct4/Sox2-regulated miR-302 targets cyclin D1 in human embryonic stem cells. Mol Cell Biol. 2008; 28: 6426-38.

52. Barroso-delJesus A, Lucena-Aguilar G, Sanchez L, Ligero G, Gutierrez-Aranda I, Menendez P. The Nodal inhibitor Lefty is negatively modulated by the microRNA miR-302 in human embryonic stem cells. FASEB J. 2011; 25: 1497-508

53. Lin SL, Chang DC, Lin CH, Ying SY, Leu D, Wu DT. Regulation of somatic cell reprogramming through inducible mir-302 expression. Nucleic Acids Res. 2011; 39: 1054-65.

54. Anokye-Danso F, Trivedi CM, Juhr D, Gupta M, Cui Z, Tian Y, et al. Highly efficient miRNA-mediated reprogramming of mouse and human somatic cells to pluripotency. Cell Stem Cell. 2011; 8: 376-88.

55. Jacobs JJ, Kieboom K, Marino S, DePinho RA, van Lohuizen M. The oncogene and Polycomb-group gene bmi-1 regulates cell proliferation and senescence through the ink4a locus. Nature. 1999; 397: 164-8.

56. Park IK, Oian D, Kiel M, Becker MW, Pihalja M, Weissman IL, et al. Bmi-1 is required for maintenance of adult self-renewing haematopoietic stem cells. Nature. 2003; 423: 302-5.

57. Molofsky AV, Pardal R, Iwashita T, Park IK, Clarke MF, Morrison SJ. Bmi-1 dependence distinguishes neural stem cell self-renewal from progenitor proliferation. Nature. 2003; 425: 962-7.

58. Okumura N, Sakamoto Y, Fujii K, Kitano J, Nakano S, Tsujimoto Y, et al. Rho kinase inhibitor enables cell-based therapy for corneal endothelial dysfunction. Sci Rep. 2016; 6: 26113.

59. Insler MS, Lopez JG. Heterologous transplantation versus enhancement of human corneal endothelium. Cornea. 1991; 10: 136-48.

60. Insler MS, Lopez JG. Extended incubation times improve corneal endothelial cell transplantation success. Invest Ophthalmol Vis Sci. 1991; 32: 1828-36.

61. Insler MS, Lopez JG. Transplantation of cultured human neonatal corneal endothelium. Curr Eye Res. 1986; 5: 967-72.

62. Gospodarowicz D, Greenburg G, Alvarado J. Transplantation of cultured bovine corneal endothelial cells to rabbit cornea: clinical implications for human studies. Proc Natl Acad Sci U S A. 1979; 76: 464-8.

63. Jumblatt MM, Maurice DM, McCulley JP. Transplantation of tissue-cultured corneal endothelium. Invest Ophthalmol Vis Sci. 1978; 17: 1135-41.

64. Lange TM, Wood TO, McLaughlin BJ. Corneal endothelial cell transplantation using Descemet's membrane as a carrier. J Cataract Refract Surg. 1993; 19: $232-5$

65. Gospodarowicz D, Greenburg G, Alvarado J. Transplantation of cultured bovine corneal endothelial cells to species with nonregenerative endothelium. The cat as an experimental model. Arch Ophthalmol. 1979; 97: 2163-9.

66. Joo CK, Green WR, Pepose JS, Fleming TP. Repopulation of denuded murine Descemet's membrane with life-extended murine corneal endothelial cells as a model for corneal cell transplantation. Graefes Arch Clin Exp Ophthalmol. 2000; $238 \cdot 174-80$

67. Aboalchamat B, Engelmann K, Bohnke M, Eggli P, Bednarz J. Morphological and functional analysis of immortalized human corneal endothelial cells after transplantation. Exp Eye Res. 1999; 69: 547-53.

68. Bohnke M, Eggli P, Engelmann K. Transplantation of cultured adult human or porcine corneal endothelial cells onto human recipients in vitro. Part II: Evaluation in the scanning electron microscope. Cornea. 1999; 18: 207-13.

69. Mimura T, Yamagami S, Amano S. Corneal endothelial regeneration and tissue engineering. Prog Retin Eye Res. 2013; 35: 1-17.

70. Lai JY, Chen KH, Hsiue GH. Tissue-engineered human corneal endothelial cell sheet transplantation in a rabbit model using functional biomaterials. Transplantation. 2007; 84: 1222-32.

71. Choi JS, Williams JK, Greven M, Walter KA, Laber PW, Khang G, et al. Bioengineering endothelialized neo-corneas using donor-derived corneal endothelial cells and decellularized corneal stroma. Biomaterials. 2010; 31: 6738-45. 
72. Liang $\mathrm{Y}$, Liu $\mathrm{W}$, Han $\mathrm{B}$, Yang $\mathrm{C}, \mathrm{Ma} \mathrm{Q}$, Zhao $\mathrm{W}$, et al. Fabrication and characters of a corneal endothelial cells scaffold based on chitosan. J Mater Sci Mater Med. 2011; 22: 175-83.

73. Watanabe R, Hayashi R, Kimura Y, Tanaka Y, Kageyama T, Hara S, et al. A novel gelatin hydrogel carrier sheet for corneal endothelial transplantation. Tissue Eng Part A. 2011; 17: 2213-9.

74. Koizumi N, Sakamoto Y, Okumura N, Okahara N, Tsuchiya H, Torii R, et al. Cultivated corneal endothelial cell sheet transplantation in a primate model. Invest Ophthalmol Vis Sci. 2007; 48: 4519-26.

75. Koizumi N, Sakamoto Y, Okumura N, Tsuchiya H, Torii R, Cooper LJ, et al. Cultivated corneal endothelial transplantation in a primate: possible future clinical application in corneal endothelial regenerative medicine. Cornea. 2008; 27 Suppl 1: S48-55.

76. Fuest M, Yam GH, Peh GS, Mehta JS. Advances in corneal cell therapy. Regen Med. 2016; 11: 601-15.

77. Mimura T, Yamagami S, Yokoo S, Araie M, Amano S. Comparison of rabbit corneal endothelial cell precursors in the central and peripheral cornea. Invest Ophthalmol Vis Sci. 2005; 46: 3645-8. 